\begin{tabular}{|c|c|}
\hline 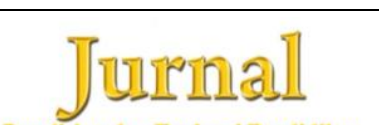 & $\begin{array}{l}\text { Jurnal Penelitian dan Evaluasi Pendidikan } \\
\text { Volume 23, No 2, December } 2019 \text { (219-229) }\end{array}$ \\
\hline idikan & Online: http://journal.uny.ac.id/index.php/jpep \\
\hline
\end{tabular}

\title{
EVALUATION OF LECTURER IN HIGHER EDUCATION CURRICULUM BASED ON THE NATIONAL STANDARDS OF HIGHER EDUCATION NO. 44 OF 2015
}

\author{
I Made Sundayana \\ Sekolah Tinggi Ilmu Kesehatan Buleleng \\ Putu Dian Prima Kusuma Dewi \\ Sekolah Tinggi Ilmu Kesehatan Buleleng \\ Putu Sukma Megaputri \\ Sekolah Tinggi Ilmu Kesehatan Buleleng
}

\begin{abstract}
The quality of education is still a benchmark of human resources (HR) in each country. The current era of revolution 4.0 requires a curriculum that is innovative, creative, and based on the needs of market share and the world of work with the addition of several new literacies. This study aims to identify and evaluate the tertiary curriculum (higher education curriculum) that has been applied in a higher education institution of health sciences in Buleleng, which refers to the national standard of higher education no. 44 of 2015. The evaluation was based on input, process, and output. The method used was the mixed method by using questionnaires and focus group discussions on 32 lecturers from the three knowledge fields of midwifery, nursing, and pharmacy. The results show that of the four standards evaluated, the learning process standard and assessment standard need to get priority in improving the academic system at the institution. Both of these components must be immediately improved in terms of concepts and understanding so that the goals, achievements, and quality of graduates can still be improved and maintained. Internal discussions and workshops should be done regularly each semester to refresh pedagogical ability and understanding of the regulatory faculty curriculum.
\end{abstract}

Keywords: evaluation, curriculum, national standard of bigher education, STIKes Buleleng

Permalink/DOI: http://dx.doi.org/10.21831/pep.v23i2.28141

\author{
Contact: I Made Sundayana \\ madesundayana@gmail.com \\ Department of Nursing, Sekolah Tinggi Ilmu Kesebatan Buleleng \\ Jl. Raya Air Sanih Km. 11, Bungkulan, Singaraja, Bali, Indonesia
}




\section{Introduction}

Curriculum is a program that can be planned and implemented to achieve a number of specific educational goals. Some very important curriculum components include goals, materials, methods, students, educators, media, environment, learning resources, and others. This curriculum component must be further developed so that the objectives or profile of the department in each institution can be achieved as appropriate (Regulation of the Minister of Research, Technology, and Higher Education No. 44 of 2015). The purpose of the existence of Law No. 12 of 2012 of Republic of Indonesia on higher education is that higher education curriculum can be developed by each tertiary institution by referring to the National Higher Education Standards (Standar Nasional-Dikti) for each study program covering knowledge, attitudes, general skills and special skills (Regulation of the Minister of Research, Technology, and Higher Education No. 44 of 2015). The issuance of the Presidential Regulation No. 8 of 2012 on the Indonesian National Qualification Framework (Kerangka Kualifikasi Nasional Indonesia or KKNI) which was later also issued by the Regulation of the Minister of Education and Culture No. 49 of 2014 which was updated to the Regulation of the Minister of Research, Technology, and Higher Education No. 44 of 2015 urged higher education so that curriculum reconstruction must refer to the national standard of the Ministry of Higher Education.

A curriculum that has been prepared by the study program can be periodically reviewed for the achievement of social and scientific relevance in accordance with what is needed by the community and the development of science and technology (National Accreditation Agency for Higher Education, 2008). Thus, the curriculum can be run by education practitioners and education targets well. Lecturers are the spearhead of implementing actors giving methods to achieve learning outcomes desired. As a lecturer must run the Tri Dharma properly and correctly, the curriculum review process carried out in stages is also related to the process of monitoring and evaluation of the Tri Dharma of Higher Education to improve the quality of community life (Wijanto, 2009).

The quality of education is still a benchmark of human resources (HR) in each country. The current era of revolution 4.0 requires a curriculum that is innovative, creative, and based on the needs of market share and the world of work with the addition of several new literacies. Some developed countries evaluate education as an initial evaluation of the quality of their human resources (Kazimirov, 2018; Tiwari, 2018). Various regulations are strived to support the achievement and improvement of the quality of Indonesian human resources. Measurement of the quality of a study program greatly determines the quality of graduates to be produced, one of the most important components is the curriculum. The curriculum is a set of plans and arrangements regarding graduate learning outcomes, study materials, processes, and assessments that are used as guidelines for organizing study programs (Regulation of the Minister of Research, Technology, and Higher Education No. 44 of 2015).

The National Higher Education Standard in the Regulation of the Minister of Research, Technology, and Higher Education No. 44 of 2015 is the minimum criterion in determining higher education standards. Of course, the tri dharma is a benchmark in its achievement, namely education, research, and community service. National education standards state that eight standards must be met. There are four important standards in an educational process, namely graduate competency standards, content standards, learning process standards, and assessment standards. New literacy according to the demands of the revolution-based higher education curriculum (Kurikulum Perguruan Tinggi or KPT) 4.0 expects data literacy, technological literacy, and human literacy to be important components in the preparation of educational standards. The industrial, market, and tertiary education sectors should establish a good partnership, so that the 
graduates produced can suit the needs in the field (Kaklauskas et al., 2018). Therefore, lecturers in this 4.0 era are required to have innovations and new learning methods not just lectures but simulations that are in line with competencies expected in the world of work (Cassano, Costa, \& Fornasari, 2019; Kazimirov, 2018). Answering the challenge, of course, there must be an appropriate curriculum and framework in the education process so that graduates are not only able to work in the world of work but also are of good quality.

When the curriculum has been prepared properly according to the needs of stakeholders, its process does not merely stop on the shape of the curriculum. Instead, it requires evaluation. Evaluation is needed in assessing the success of a standard that has been applied. Evaluation is divided into internal and external evaluations. Evaluation of modern education places an assessment of learning outcomes at the center in the evaluation process, and evaluation of the "teacher" as a role model of change (Tiwari, 2018). The big challenge faced by tertiary education in Indonesia today is developing learning outcomes that fit the needs of the community and industry. Higher education in the health field often have difficulties in this implementation because most of the products are in the form of services of health workers. Before compiling a graduate learning achievement (Capaian Pembelajaran Lulusan or CPL), the most important input is the understanding and innovation of resources, one of which is the lecturer. The ability of lecturers to master CPL and related regulations will largely determine the direction and outputs of graduates (Cassano et al., 2019; Pribadi, 2019).

This study aims to identify and evaluate the tertiary curriculum (KPT) that has been applied in Sekolah Tinggi Ilmu Kesehatan (STIKes) Buleleng, which refers to the National Standard of Higher Education in the Regulation of the Minister of Research, Technology, and Higher Education No. 44 of 2015, which is important as a benchmark and internal quality assurance.
STIKes Buleleng, as one of the health higher education institutions in the North Bali region, must always be able to maintain the quality of health workers produced.

\section{Research Method}

This research took place in August 2019 involving all lecturers in STIKes of Buleleng from six Study Programs and three fields of science, namely, midwifery, nursing, and pharmacy. The number of lecturers involved in this study was 32 people who were spread in those three fields of science. This study used a mixed-method (quantitative-qualitative) to assess the evaluation and implementation of a curriculum that has been implemented, including the level of understanding of STIKes Buleleng lecturers of the higher education curriculum referring to the national standard of Higher Education in the Regulation of the Minister of Research, Technology, and Higher Education No. 44 of 2015. Data were collected through the questionnaire and focus group discussion (FGD). The questionnaire was distributed online via the WhatsApp group. The online instrument can be accessed through this link http://bit.ly/Eval_Pend.

The questionnaire compiled consisted of several questions divided into four components to evaluate input, process, and output, namely competency standard (four questions), content standard (10 questions), learning process standard (14 questions), and assessment standard (five questions). The questionnaire was compiled based on references from the national standard of higher education and then developed according to the needs. The content analysis, validity, and reliability processes were previously carried out to the questionnaire to assess the validity of the questions given. The questions were compiled using Bloom's taxonomic reference to evaluate the components of national standards and the higher education curriculum. The questions for the FGD were divided into 16 questions to assess qualitatively. FGD activities were divided into two groups within two days. 
The data obtained were subsequently through the tabulating, editing, and clearing stages before further analysis. The data obtained were then analyzed using software assistance, namely NVIVO 12 Plus and SPSS version 17. The NVIVO 12 Plus software was used to help see the essence and mindset of each respondent for the questions given, while SPSS version 17 software was used to analyze the data quantitatively.

\section{Findings and Discussion}

The results of the evaluation and implementation of the higher education curriculum are viewed from the four main standards by looking at the inputs, namely the lecturer. These four standards refer to the national standard of Higher Education No. 44 of 2015 concerning national education standards. Demographic analysis can be seen in Table 1.

Table 1. Respondent Demographic Conditions

\begin{tabular}{ll}
\hline Variable & $\mathbf{f ~ ( \% )}$ \\
\hline Age (Mean \pm SD) & $30.8 \pm 5.48$ \\
Length of working (Mean \pm SD) & $5.34 \pm 3.55$ \\
Position & $16(50.0)$ \\
Yes & $16(50.0)$ \\
No & \\
Study Program & $14(43.8)$ \\
Midwife & $16(50.0)$ \\
$\quad$ Nurses & $2(6.3)$ \\
Pharmacy & \\
Last Education & $4(12.5)$ \\
S1 & $27(84.3)$ \\
S2 & $1(3.2)$ \\
S3 & \\
\hline
\end{tabular}

Table 1 shows that the average age of lecturers at STIKes Buleleng is 30.8 or 31 years old, with the working period of more than five years, and largely comes from the field of obstetrics and nursing. In addition, $50 \%$ of the respondents are also in structural and functional positions. These results indicate that the majority of lecturers are in the productive age range, in which this age range has high potential and enthusiasm for work, especially has a high level of innovation as well as creativity owned (Kazimirov, 2018; Setyawati, 2015).
An educator plays an important role as facilitator, motivator, and inspiration for the learners in the learning process. Continuous innovation is needed to produce smart, creative, independent, and responsible students (Setyawati, 2015). The results of this study also found that the last education of the most human resources involved in this study was the master's degree, as many as $84.3 \%$.

Input

\section{Graduate Competency Standard}

In this standard, there are many indicators arranged. Those indicators are listed in Table 2.

Table 2. Indicators of Graduates Competency Standard

\begin{tabular}{ll}
\hline Variable & $\mathbf{f ~ ( \% )}$ \\
\hline SN Dikti Knowledge & \\
$\quad$ Yes & $31(96.9)$ \\
$\quad$ No & $1(3.1)$ \\
Compilation of Competencies of & \\
Graduates & \\
$\quad$ Correct & $30(93.8)$ \\
$\quad$ Incorrect & $2(9.4)$ \\
\hline
\end{tabular}

The aforementioned results show that almost all lecturers know about the national standard of higher education stated in the Regulation of the Minister of Research, Technology, and Higher Education No. 44 of 2015 and know that graduate competencies are prepared based on the stakeholder input or the demand of the industry. The quantitative results above are different from the qualitative study results. As illustrated in Figure 1, in the FGD, some respondents are still ambiguous between graduate competency or graduate profile with the CPL courses, evidenced by the results obtained that almost all lectures answer that the CPL subjects that are taught are not CPL from the study program. The mindset found that the study program CPL and course CPL are regarded as the same thing despite having different meanings both in content and formulation. Study program CPLs are compiled from agreements and input from stakeholders, while course CPLs are derived from 
curriculum maps based on study material (Regulation of the Minister of Research, Technology, and Higher Education No. 44 of 2015). Only two respondents named study program CPL that "produces care provider midwives and professional nurses in the field of HIV/AIDS".

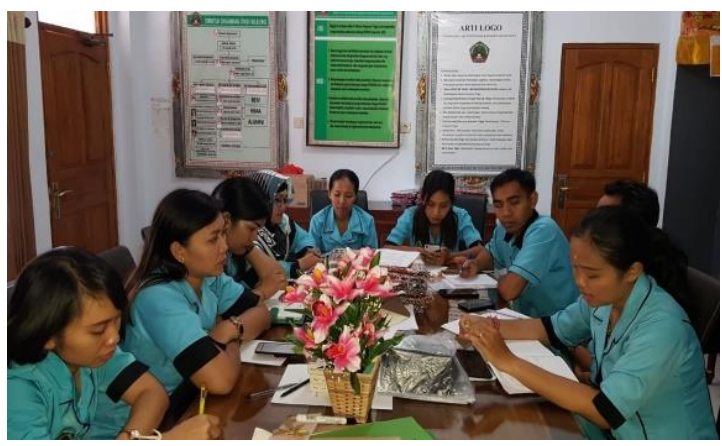

Figure 1. FGD Process Step One

\section{Content Standard}

In this phase, FGD step two was carried out, illustrated in Figure 2. In addition, Table 3 shows that $90.6 \%$ of lecturers never reviewed the syllabus that had been prepared with the process of preparing incorrect syllabus to $53.1 \%$. Nevertheless, most of the lecturers $(84.4 \%)$ knew that the syllabus is the responsibility of lecturers, with minimal components that are suitable with the national standard of Higher Education as stated in the Regulation of the Minister of Research, Technology, and Higher Education No. 44 of 2015 (56.3\%). This content standard includes criteria for a minimum level of depth and breadth of learning material (Regulation of the Minister of Research, Technology, and Higher Education No. 44 of 2015).

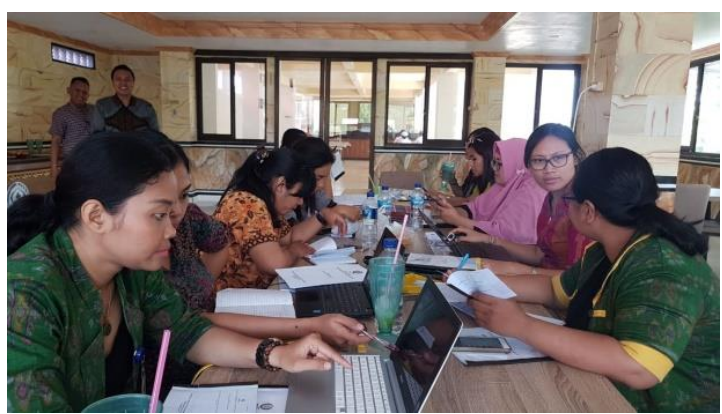

Figure 2. FGD Process Step Two
Table 3. Criteria for Content Standard

\begin{tabular}{ll}
\hline Variable & $\mathbf{f ~ ( \% )}$ \\
\hline Have reviewed RPS & $3(9.4)$ \\
$\quad$ Yes & $29(90.6)$ \\
$\quad$ No & \\
Completing RPS & $27(84.4)$ \\
$\quad$ Correct & $5(15.6)$ \\
$\quad$ Incorrect & \\
Minimum Components & $18(56.3)$ \\
$\quad$ Right & $14(43.8)$ \\
$\quad$ Wrong & \\
RPS Sequence & $15(46.9)$ \\
$\quad$ Correct & $17(53.1)$ \\
$\quad$ Incorrect &
\end{tabular}

The stages of drafting the Higher Education Curriculum (KPT) include (1) determining graduate profiles and learning outcomes (CPL), (2) evaluating each course on the old curriculum structure, (3) selecting and arranging learning materials, (4) composing courses, curriculum structure, and determining semester credits (Sistem Kredit Semester or SKS), and (5) developing learning plans (Pribadi, 2019; Regulation of the Minister of Research, Technology, and Higher Education No. 44 of 2015). The levels of depth and breadth of learning material are decisive in the success of a student's learning and achievements (Luttenberger et al., 2018).

The preparation of the syllabus is an important thing to do. The syllabus is one of the guidelines in the whole semester's learning process so the process of preparing the syllabus requires the team's assistance in doing everything. Oftenly, the syllabus cannot be used as a guide by students and lecturers to design learning and assignment due to its too narrow, too general, or too rigid arrangement so it does not give flexibility to lecturers and students. Such learning experiences will complicate and weaken students' motivation to learn (Hussey \& Smith, 2010).

\section{Learning Process Standard}

FGD step three was carried out as illustrated in Figure 3. Besides, Table 4 shows that most lecturers have a good understanding of the learning process standard as seen from the percentage of correct answers from the qualitative learning and determination of effective weeks in each semester. 


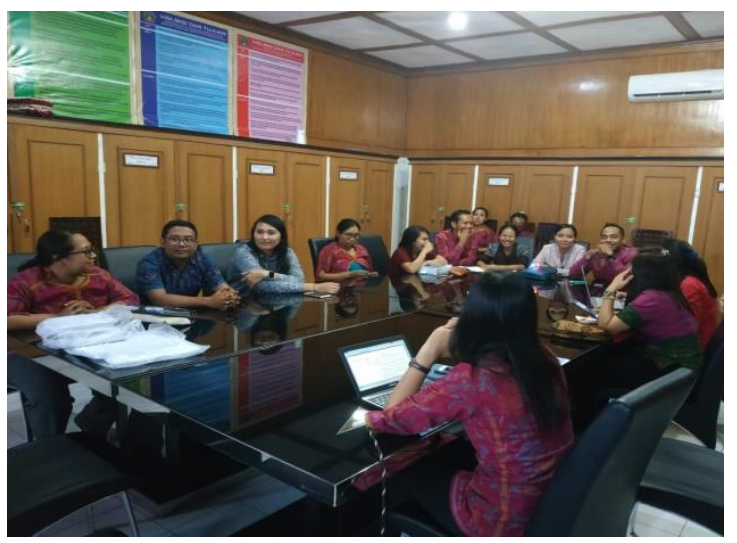

Figure 3. FGD Process Step Three

Table 4. Criteria for Learning Process Standard

\begin{tabular}{ll}
\hline Variable & $\mathbf{f ( \% )}$ \\
\hline Learning Method & $26(81.3)$ \\
$\quad$ Correct & $6(18.8)$ \\
$\quad$ Incorrect & \\
Form ofLearning & $21(65.6)$ \\
$\quad$ Correct & $11(34.4)$ \\
Incorrect & \\
Amount of 1 SKS & $24(75.0)$ \\
$\quad$ Correct & $8(25.0)$ \\
$\quad$ Incorrect & \\
Amount Effective Week & $25(78.1)$ \\
$\quad$ Correct & $7(21.9)$ \\
Incorrect & \\
Amount Seminar Time & $24(75.0)$ \\
$\quad$ Correct & $8(25.0)$ \\
Incorrect & \\
Amount Practical Time & $27(84.4)$ \\
$\quad$ Correct & $5(15.6)$ \\
Incorrect & \\
Amount of Structured Assignment & \\
Time & $25(78.1)$ \\
$\quad$ True & $7(21.9)$ \\
$\quad$ False &
\end{tabular}

According to the national standard of higher education no. 44 of 2015, the principles of the assessment refer-red to in Article 19 paragraph (2) letter 'a' include the principles of educative, authentic, objective, accountable, and transparent which are carried out in an integrated manner (Regulation of the Minister of Research, Technology, and Higher Education No. 44 of 2015).

Each form of learning should be determined by regulations in accordance with the targets and levels of education or achievements that have been prepared (Kazimirov, 2018). In the national standard of higher education number 44 of 2015, the learning process standard is the third important standard applied in the KPT. The learning process standard is a criterion for determining each minimum allocation of forms on the implementation of learning in the study program to obtain the learning outcomes of graduates (Regulation of the Minister of Research, Technology, and Higher Education No. 44 of 2015).

The initial lecture conducted by lecturers is mostly done by giving syllabus to students at the initial meeting. Thus, it is found that very few lecturers did not make or give syllabus to their students. It indicates that the learning process becomes more relevant, motivates students to learn, focuses on student needs, presents meaningful learning, and helps students to be independent and supports lifelong learning (Sitepu \& Lestari, 2018).

\section{Assessment Standard}

"The principle of learning assessment done is objective and transparent" is the answer most oftenly raised by lecturers. This answer is not an incorrect thing, but it does not cover all the principles of minimum assessment on the assessment standards at the national standard of higher education. The principles in the assessment include the principles of educative, authentic, objective, accountable, and transparent assessment carried out in an integrated manner (Regulation of the Minister of Research, Technology, and Higher Education No. 44 of 2015). The educational principle referred to is an assessment that motivates students to be able to improve planning and learning methods; and achieve learning outcomes of the graduates.

Authentic educative principle is implicit in the rubric assessment arranged either form of essays and portofolio. The most oftenly mentioned assessment rubric is the cognitive and psychomotor assessment rubric in addition to the essay rubric and portfolio. Assessment as a tool to evaluate students' progress on the main dimensions of learning so that a process needs to be sustainable and comprehensive, which has been 
highly emphasized in all the latest educational documents, especially in the National Curriculum (Tiwari, 2018).

\section{Human Resource Standard}

Input process in the implementation of learning requires human resources aspect. Human resources include lecturers and educational staff. In accordance with the national standard of higher education number 44 of 2015, it is explained that the criteria for a lecturer is to have a minimum master degree education (Regulation of the Minister of Research, Technology, and Higher Education No. 44 of 2015). Education resources become an important factor which will provide input, new knowledge, and new experiences for students they educate. The results of this study report that (Table 1) the majority of lecturers fit the criteria of the national standard of higher education, which is, having the master degree education. The results of previous studies also found that the qualifications of an educator must meet the desired competencies so that the learning process runs smoothly and the CPL can be achieved (Rahmawati \& Anggraini, 2017).

\section{Process}

The process that has been carried out by lecturers based on the national standard of higher education in the Regulation of the Minister of Research, Technology, and Higher Education No. 44 of 2015 are including competency standard, content standard, learning process standard, and assessment standard. The results are described qualitatively and quantitatively as follows.

\section{Graduate Competency Standard}

The results of the FGD show that the CPL component had been prepared and established clearly, in detail, and was contained in the syllabus that had been prepared by the needs and profile of graduates in each study program. Most lecturers (84.3\%), before conducting lectures, had given syllabus and lecture contracts. There are $15.6 \%$ of lecturers who consider syllabus is less important than the academic calendar.
Competency standards are the main point in starting a process in the Study Program. This standard is like a map so that all components do not lose direction of the objectives to be achieved (Kazimirov, 2018; Pribadi, 2019; Rodríguez-Conde, OlmosMigueláñez, Gamazo, \& O’Hara, 2018; Tiwari, 2018).

\section{Content Standard}

Content standards include minimal components that must be designed and stated in the curriculum. The content standard becomes the next reference after the competency standard which has been determined from the beginning.

Based on the results of the questionnaire that almost all lecturers (97.8\%) mentioned that in the process of preparing the syllabus conducted by lecturers supporting the course, only $3.2 \%$ stated that the syllabus was prepared according to the authorization of the head of the study program. The process of preparing the syllabus conducted at the beginning of the semester also includes the quality control process of the curriculum development unit (Unit Pengembangan Kurikulum or UPK) in STIKes Buleleng.

The results of the FGDs conclude that the existence of the the UPK was very beneficial for the lecturers, especially to be able to become an external assessment of the syllabus and the tools that had been prepared. Besides, evaluation and monitoring are also carried out both in the middle and end of the semester, by looking back at the lecturers' teaching journals. This process is carried out by the course coordinator lecturer, which is then reported to the chair of the study program.

Related to the content in the syllabus, it is not $100 \%$ done through a face-to-face meeting, but also done online between 10$20 \%$ of the learning material provided. The blended learning process is still in the trial process that is implemented at STIKes Buleleng. Various components and readiness in terms of lecturers' abilities, content developed, and students' readiness to accept this process also need to be reviewed. The sem- 
ester learning plan (syllabus), task design, Learning Achievement of Courses (Capaian Pembelajaran Mata Kuliah or CPMK), learning materials, and learning methods are components that are often out of sync in the learning tools that have been prepared so that the monitoring process needs to be done.

\section{Learning Process Standard}

After competency standards and content standards are met, the next is the standard of the learning process. In this case, it is not only centered on lecturers but also students. The process and form of learning are often two things that are difficult to distinguish. The form of learning is a method used to fulfill the specified learning process. The learning process is bound to the unit of time specified in the regulation (Pribadi, 2019; Regulation of the Minister of Research, Technology, and Higher Education No. 44 of 2015).

Some lecturers mentioned that the learning process is the same as the form of learning. The process and form of learning are considered as a single entity that cannot be distinguished. This statement also affects the time allocation process specified in each learning process.

The results obtained at the process stage are that the method applied is in line with the study material that has been prepared, including the learning outcomes to be achieved. All components of the CPMK are translated in the form of Bloom's taxonomy from cognitive, affective, and psychomotor aspects.

The results of observations on this aspect of the process were also seen from the existing lecturer teaching journal documents which were then checked with each student who was responsible for the course. Based on the results of the interview, there is no learning process which is not by the syllabus or study material from the three fields of science. Face to face meeting must have been conducted at least 14 times outside of the guidance and discussion process which is always opened through media facilities, such as WhatsApp and group e-mails.
The synchronization between the syllabus, task design, description of methods, and study material in input will determine the process carried out next (Hartini \& Suryanti, 2019). In addition to synchronization, a pedagogical ability of lecturers has also been proven to affect the learning motivation of students (Rahman, Mutiani, \& Putra, 2019). Lecturers become role models indirectly for students, then their attitude is demanded to be good so they can also give good examples.

\section{Assessment Standard}

The results of lecturer evaluations on the standard components of this assessment indicate that each course has a clear assessment rubric and is listed in the syllabus. All the assessment principles specified in the Regulation of the Minister of Research, Technology, and Higher Education No. 44 of 2015 are contained in the rubric of assessment and syllabus prepared by lecturers. The most widely applied components are fair, objective, accountable and transparent. The principle of assessment as referred to in article 19 paragraph (2) letter ' $a$ ' includes the principles of education, authentic, objective, accountable, and transparent which are carried out in an integrated manner.

The results of observations in this study show that the compiled syllabus shows the assessment components included in the final syllabus sheet and refers to the academic guidelines that apply to STIKes Buleleng. Remedial is an educational evaluation principle carried out transparently and accountably by announcing the score obtained and then evaluating the components that have not yet been achieved. In the component of the education standard at the national standard of education number 44 of 2015, the assessment standard is the most important component at the end of an educational process. Learning appraisal standard is a minimum criterion on the assessment of student learning processes and outcomes in the context of fulfilling graduate learning outcomes (Regulation of the Minister of Research, Technology, and Higher Education No. 44 of 2015). 
The FGD process related to the assessment standards showed that the final results of the assessment that had been carried out included the remedial process, reported to the lecturer coordinator of the course and the head of the study program at the end of the semester. The assessment process is the end of the evaluation process of a learning process by considering all aspects assessed (Bashri, Puspitawati, \& Ibrahim, 2018; Hartini \& Suryanti, 2019; Rahman et al., 2019; Regulation of the Minister of Research, Technology, and Higher Education No. 44 of 2015).

\section{Output}

\section{Graduate Competency Standard}

The syllabus is by the requirements of the national standard of higher education wherein its preparation should follow the existing minimum standards according to the the standards listed there. In the syllabus, the name of the study program, courses, semesters, credits, lecturers' names applicants, graduate learning outcomes, expected end skills, study materials, learning methods, the time provided, student learning experiences, criteria, indicators and assessment weight, and the list of available references are arranged (Regulation of the Minister of Research, Technology, and Higher Education No. 44 of 2015).

The lecturers' syllabus study compiled with the team is also evaluated in terms of output. Most of the lecturers, in the preparation of the syllabus, have collaborated with the team following the various decree of the chairperson. When the syllabus drafting team and its teaching team have been determined, the lecturer starts a discussion related to the study material included to obtain the CPL that the study program wants.

Adequate and standardized curriculum documents now also exist in universities. This curriculum document is used by each study program as a guide in learning. The existence of a Curriculum Development Team that has carried out an internal evaluation of the quality, quantity, and quality of the syllabus prepared is also very useful. The curriculum development team has an external monitoring and evaluation function for this learning activity. After the learning process is complete, the curriculum developer unit will evaluate the learning process that has already taken place. This result is good enough to be done so that the desired competency standard output will be easily met.

\section{Content Standard}

The components in a syllabus are following the demands of the higher education national standard and the KPT that lead to the revolution 4.0. Revolution 4.0 emphasizes more on students' creativity and reasoning power. Almost all of the study programs owned by STIKes Buleleng include reasoning and creativity as a form of application of mental revolution 4.0. Students are required to have good critical thinking and critical reasoning by including entrepreneurship courses as an initial capital. The output of this course is to produce a model, prototype, or another thing that focuses on decreasing the degree of pain and death.

\section{Learning Process Standard}

The method used is following the content presented. Judging from the lecturers' journals, they were following the implementation time, the methods used, and the material presented. This result is seen when the quality assurance institute and study programs, as quality control groups, monitor the learning process. The absent journal that was made at STIKes Buleleng gave rise to the sections of learning material, student attendance, learning methods, and lecturer attendance. To evaluate the suitability of the syllabus with the correct occurrence, it is listed in the journal of lecturer and student activities. Most of the lecturers at STIKes Buleleng have implemented learning methods that are following those listed in the syllabus.

\section{Assessment Standard}

The student assessment process is the result of a learning process. The resulting output is a form of assessment which can 
validly and reliably collect student grades according to the actual assessment. The assessment technique uses a rubric. The rubric used is following the material or content in the syllabus. The type of assessment rubric should be following the evaluation technique used, so that objectivity in the assessment process can be achieved. The rubric used is also standardized according to national standard of higher eeducation so that the assessment, assessment process, and the results obtained are the results of an objective assessment.

\section{Conclusion}

Based on the research findings, it is concluded that the evaluation and implementation of the higher education curriculum based on the national standard of higher education in the Regulation of the Minister of Research, Technology, and Higher Education No. 44 of 2015 needs to be improved from the standard components of learning content and assessment. Both of these components must be immediately improved in terms of concepts and understanding so that the goals, achievements, and quality of graduates can still be improved and maintained. Internal discussions and workshops should be done regularly each semester to refresh pedagogical ability and understanding of the regulatory faculty curriculum.

\section{References}

Bashri, A., Puspitawati, R. P., \& Ibrahim, M. (2018). Efektivitas pelaksanaan kurikulum di program studi Pendidikan Biologi Universitas Negeri Surabaya. Jurnal Penelitian Pendidikan Matematika Dan Sains, 2(1), 1-5. Retrieved from https://journal.unesa. ac.id/index.php/jppms/article/view/ 6213

Cassano, R., Costa, V., \& Fornasari, T. (2019). An effective national evaluation system of schools for sustainable development: A comparative European analysis.
Sustainability, 11(1), 195. https://doi. org/10.3390/su11010195

Hartini, S., \& Suryanti, H. H. S. (2019). Analisis sinkronitas rencana pembelajaran semester (RPS) dengan rencana tugas semester mahasiswa (RTM) dan rencana evaluasi pembelajaran (REP) dosen FKIP Unisri tahun 2018. Research Fair Unisri, 3(1). Retrieved from http://ejurnal. unisri.ac.id/index.php/rsfu/article/vi ew/2620

Hussey, T., \& Smith, P. (2010). The trouble with higher education: A critical examination of our universities. https://doi.org/ 10.4324/9780203866344

Kaklauskas, A., Banaitis, A., Ferreira, F., Ferreira, J., Amaratunga, D., Lepkova, N., ... Banaitiené, N. (2018). An evaluation system for universityindustry partnership sustainability: Enhancing options for entrepreneurial universities. Sustainability, 10(1), 119. https://doi.org/10.3390/su10010119

Kazimirov, A. N. (2018). Education at university and industry 4.0. Proceedings of 2018 Global Smart Industry Conference (GloSIC 2018), 1-6. https://doi.org/ 10.1109/GloSIC.2018.8570076

Law No. 12 of 2012 of Republic of Indonesia on Higher Education. , (2012).

Luttenberger, S., Macher, D., Maidl, V., Rominger, C., Aydin, N., \& Paechter, M. (2018). Different patterns of university students' integration of lecture podcasts, learning materials, and lecture attendance in a psychology course. Education and Information Technologies, 23(1), 165-178. https:// doi.org/10.1007/s10639-017-9592-3

National Accreditation Agency for Higher Education. (2008). Buku II: Standar dan prosedur akreditasi program studi sarjana. Jakarta: National Accreditation Agency for Higher Education, Ministry of National Education. 
Presidential Regulation No. 8 of 2012 on the Indonesian National Qualification Framework. , (2012).

Pribadi, H. (2019). Implementasi kurikulum perguruan tinggi (KKNI dan SNDikti) pada program studi sarjana Bimbingan dan Konseling Universitas Borneo Tarakan. Proceeding of Konvensi Nasional XXI Asosiasi Bimbingan Dan Konseling Indonesia, 39-46. Retrieved from http://proceedings.upi.edu/ index.php/konvensiabkinxxi/article/ download/448/402/

Rahman, A. M., Mutiani, M., \& Putra, M. A. H. (2019). Pengaruh kompetensi pedagogik dosen terhadap motivasi belajar mahasiswa Pendidikan IPS. Jurnal Darussalam: Jurnal Pendidikan, Komunikasi Dan Pemikiran Hukum Islam, 10(2), 375-387. https://doi. org/10.30739/darussalam.v10i2.380

Rahmawati, D., \& Anggraini, A. D. (2017). Evaluasi program kurikulum berdasarkan standar isi, standar proses, dan standar kompetensi lulusan di SDN Pisangan Timur 10 Pagi. Jurnal Pendidikan Ekonomi Dan Bisnis (JPEB), 5(1), 35-50. https:// doi.org/10.21009/JPEB.005.1.3

Regulation of the Minister of Education and Culture No. 49 of 2014 on the National Standard of Higher Education. , (2014).

Regulation of the Minister of Research, Technology, and Higher Education No. 44 of 2015 on the National Standard of Higher Education. , (2015).

Rodríguez-Conde, M.-J., OlmosMigueláñez, S., Gamazo, A., \& O'Hara, J. (2018). Evaluation in education and guidance: A perspective from 2018. Proceedings of the Sixth International Conference on Technological Ecosystems for Enhancing Multiculturality TEEM'18, 129-133. https://doi.org/ $10.1145 / 3284179.3284203$

Setyawati, R. (2015). Peran guru bahasa dan sastra Indonesia dalam pembelajaran yang inovatif. Buana Bastra, 2(2), 165174. Retrieved from http://jurnal. unipasby.ac.id/index.php/bastra/arti cle/view/231

Sitepu, B. P., \& Lestari, I. (2018). Pelaksanaan rencana pembelajaran semester dalam proses pembelajaran di perguruan tinggi. Perspektif Ilmu Pendidikan, 32(1), 41-49. https://doi. org/10.21009/PIP.321.6

Tiwari, S. K. (2018). Evaluation of modern education system in India: Problem and opportunities. International Journal of Advanced Research and Development, 3(2), 468-470.

Wijanto, S. (2009). Pengelolaan perguruan tinggi secara efisien, efektif dan ekonomis (Untuk. meningkatkan mutu penyelenggaraan Pendidikan dan mutu lulusan). Jakarta: Salemba Empat. 